\title{
Intersections of Migration and Education from the Perspective of International Law
}

\author{
Ekaterina V. KISELEVA \\ Department of Public International Law \\ Peoples' Friendship University of Russia (RUDN University) \\ Moscow, Russia \\ kiseleva_ev@gmail.com
}

\begin{abstract}
In context of reviewing several Sustainable Development Goals through the mechanism of UN Highlevel Political Forum in 2019, the purpose of this paper is to enrich the dialogue on the interconnection and mutual influence between different goals in the example of Goals 4 , 8 and 10 relating to migration and education. Both migration and education can be found in the Declaration, and goals and targets, specifically. The issues of migration and education are intertwined in many aspects. The three points were chosen from the many mentioned in the development agenda, which are the access of migrant children to education, the quality of that education in context of integration problems faced by children and educational systems and education in the field of migration, and academic migration. As an illustration to the problems raised, the experience of the Russian Federation is taken, as this country is in the top-list of migrants receiving states for years. Education on migration is taken at the example of the most settled part of migration sphere in law, which is the refugee law, with the links between theory and clinical experience of law students. Finally, the academic migration is touched upon through concepts of "brain drain", "brain circulation" and "brain waste".
\end{abstract}

\section{Keywords-International law; Migration; Education}

\section{INTRODUCTION}

In September 2015 a new agenda for sustainable development was adopted to cover a period of 2016-2030. It is entitled "Transforming our world: the 2030 Agenda for Sustainable Development" [1] and sets 17 Sustainable Development Goals (SDGs), followed by 169 targets. Both migration and education can be found in the text of the Declaration, and goals and targets, specifically. On many points the issues of migration and education are intertwined. In 2019, through the mechanism of UN High-level Political Forum established in 2013, the three goals that are most relevant to the topic of the present article are to be reviewed in depth (among others), we mean Goals 4, 8 and 10, on inclusive and equitable quality education, sustained inclusive and sustainable economic growth, and reducing inequality within and among countries, correspondingly. Approaching the intersections of migration and education from the point of international law, we aim at enriching the dialogue on the interconnection and mutual influence between different goals. The three points were chosen for this, they are the access of migrant children to education and the quality of that education in context of integration problems that the children and educational systems face, education in the field of migration, and academic migration. As an illustration to the problems raised, the experience of the Russian Federation is taken, as this country is in the top-list of migrants receiving states for years ${ }^{1}$. Education on migration is taken at the example of the most settled part of migration sphere in law, which is the refugee law, with the links between the theory and clinical experience of the law students. Finally, the academic migration is touched upon via concepts of 'brain drain', 'brain circulation' and 'brain waste'.

\section{INCLUSIVE AND EQUITABLE QUALITY EDUCATION FOR MIGRANT CHILDREN}

The right to education is proclaimed in and guaranteed by many international legal documents [see 4]. To name just a few, the list will include the Universal Declaration of Human Rights, 1948 (para. 1 Art. 26), the International Convention on the Elimination of All Forms of Racial Discrimination, 1965 (para. (e) "v" Art. 5), the International Covenant on Economic, Social and Cultural Rights, 1966 (Art. 13-14), the Convention on the Elimination of All Forms of Discrimination against Women, 1979 (Art. 10), the Convention on the Rights of the Child, 1989 (Art. 28-29), the Convention on the Rights of Persons with Disabilities, 2006 (Art. 24). In respect of a migration situation, the right to education is codified in Art. 30 and 43 of the International Convention on the Protection of the Rights of All Migrant Workers and Members of Their Families, 1990.

\section{A. Inclusive education in respect of migrant children}

The problems with implementation of inclusive education in respect of migrant children are the best revealed by the issue of refusing irregular migrant children (or the children of irregular migrants) to be enrolled in educational institutions.

\footnotetext{
${ }^{1}$ From the beginning of the 90 s XX century and up to 2015 , Russia was the second migrants receiving country in the world. In 2015 Russia with 11,9 million migrants conceded the second place to Germany with 12 million migrants [2, p. 5]. At present Russia is the forth after the USA, Saudi Arabia and Germany [3].
} 
Article 30 of the International Convention on the Protection of the Rights of All Migrant Workers and Members of Their Families, 1990, states that "Each child of a migrant worker shall have the basic right of access to education on the basis of equality of treatment with nationals of the State concerned. Access to public pre-school educational institutions or schools shall not be refused or limited by reason of the irregular situation with respect to stay or employment of either parent or by reason of the irregularity of the child's stay in the State of employment." This article is located in part III of the Convention which extends to all migrants, irrespective to complying with all rules of law of the state of employment (receiving state).

Although the majority of migrants receiving states participate in the International Covenant on Economic, Social and Cultural Rights, 1966, and the Convention on the Rights of the Child, 1989, but not in the International Convention on the Protection of the Rights of All Migrant Workers and Members of Their Families, 1990, the uniformity of the interpretation of the right to education with respect to migrants by all three treaty bodies (established on basis of the above-mentioned international treaties), including the most recent general comments, leaves no other option but to agree with the fact that contemporary understanding of the right to education extends this right to all children in the territory of the country regardless of migration status and regardless of a state's participation in the 1990 Convention. In Russia, for example, both the analysis of domestic law and judicial practice are consistent with this conclusion. In particular, in its decision of August 27, 2015, No. AKPI15-694, the Supreme Court of the Russian Federation confirmed that the lack of documents on legalization in the territory of the Russia on the part of migrant parents is not a reason for refusing to admit a child to an educational organization if there are free places in the latter. Such reading guarantees the right to education for children of migrants of any category (who are in compliance with applicable law or in violation of any rules, who are labour migrants or asylum seekers, persons in process of determination of their status, or who have not received access to the procedure at the time in question, or any other). However, practical problems in this part remain.

\section{B. Equitable quality education}

Equitable quality education is regularly challenged when there are the so-called 'migrant schools' or 'migrant classes', i.e. schools/classes with considerable proportion of children not fluent or not speaking the language of instruction (this issue, of course is linked to inclusiveness, too).

On some occasions this can really reveal the policy of segregation, resulting in the lower quality of education for migrant children. However, there can be the opposite use of the special schools/classes where the number of migrant children is high. For example, programme documents of the Russian Federation (Decree of the President of the Russian Federation, dated May 7, 2012, 'On ensuring inter-ethnic peace and harmony', para. 17 and para. 23e of the Concept of the State Migration Policy of the Russian Federation, dated June 13, 2012, and, to a lesser extent, paras. $21 \mathrm{~b}, 23$ and $27 \mathrm{v}$ of the Concept of the State Migration Policy of the Russian
Federation for 2019-2025, dated October 31, 2018, the Strategy of the State National Policy of the Russian Federation, dated December 19, 2012, link mastering the Russian language with successful integration into the Russian society, with prevention of international conflicts, and, therefore, do not leave room for interpretation of such a concentration of migrant children as measures of segregation. On the contrary, special measures for such children (additional classes in the Russian language, training in Russian as non-native programs, etc.) are integrational in their nature and content, and are encouraged by the General Comment No. 23 adopted by the Committee on Rights of the Child together with the Committee on the Rights of Migrant Workers in 2017 (paras. 62-63).

Reaching the goal of inclusive and equitable quality education in respect of migrant children, thus, calls for some steps that can be summarized as follows: information is essential as basis for action. So, the data on the distribution of migrant children within regions, localities, schools are important and shall be gathered and analyzed on local, state and, possibly, international level; states shall be encouraged to formulate clear policies regarding integration of migrant children via the educational system with the idea that 'not only the best students matter for the state' to be brought into the inter-states discussions, as schools in a difficult social context, working with children at risk of school failure, in the interests of stability of the state should be considered along with schools for gifted children as eligible for additional measures of support from the state; best practices shall be compiled and shared, e.g. about the development of methodological materials on the state language as non-native, methodological materials for subjects teachers working with children with little or no command of the state language, teacher and teacher-to-be training programs and courses for working with children who have little or no command of the state language.

\section{EDUCATION OF LAW STUDENTS IN THE FIELD OF MIGRATION}

As a separate systemic measure for the mentioned in part II above to be implemented, the education of the future law- and policy-makers in the field of migration (specifically, from the international prospective) seems to be essential. With due respect to the diversity of approaches to educating lawyers, the experience of the Russian Federation can be used as one of the models to tackle the issue.

The empirical information for the statements below were gathered for the two seminars (one about teaching the refugee law in frames of the legal education in Russia [5] and the other about the potential of university legal clinics to work with migrants and refugees [6]).

\section{A. Curricula in law and teaching refugee law}

The empirical base was formed by the answers of 25 seminar participants representing educational and human rights organizations of 11 subjects of the Russian Federation, of whom there were 3 doctors of science (double $\mathrm{PhD} ; 2$ in law, 1 in history), 15 candidates of science ( $\mathrm{PhD} ; 10$ in law, 3 in history, 1 in political studies, 1 in philology) and 7 persons 
without a $\mathrm{PhD}$ degree. By the criterion of academic title, there were 2 professors, 11 doctors, 12 persons without a title.

The survey showed that 20 of the 25 participants experience in teaching refugee law, while those without such experience are representatives of the practice ( 2 persons) and those who are only to start such activities ( 3 persons). A number of participants have experience in teaching refugee law not at a university, e.g. on advanced training programs for civil servants (3 responses), police officers (2 responses), special department for migration (2 responses), social workers, etc.

Out of the 20 persons teaching refugee law, only two have specialized disciplines (both in the international legal prospective), while the rest include refugee law as a topic in other courses (approximately half of the respondents indicated one course, others did from 2 to 4 ).

The general course of public international law was named as the most popular for a brief overview of the legal problems of forced migrants ( 8 responses), as well as disciplines of a similar level of fundamentality and breadth, reflecting the nonbachelor level of training, non-international legal or non-legal specialization of the target audience (6 responses). After public international law, the most popular answer was variations on the topic of specialized discipline on migration (6 responses) and human rights subjects (4 responses).

Analysis of the amount of hours for refugee law showed a diversity. An approximately equal number of responses were given for 1-2 hours (5 responses), 3-4 hours (5 responses), 5-8 hours (3 responses), 10-20 hours, inclusive (6 answers) and more than 20 hours ( 4 responses). This means that every second teacher can devote 3 to 4 hours of a class time to refugee law, and a little less than half can devote even more. An extension of teaching refugee law was considered as important and necessary by all the participants of the seminar, except for one.

Summarizing, we can note that the refugee law is a popular subject. Its inclusion in the educational process requires more flexibility of teachers in the use of available resources rather than radical changes in the curriculum in the form of the introduction of an independent discipline. An invaluable source for deepening and widening of teaching refugee law is the UNHCR, whose representations do so much to popularize the topic of refugees as part of the educational process, improve the skills of teachers in this part and expand the range of available useful materials on refugee law.

\section{B. Clinical practice and the needs of migrants and refugees}

The survey about the legal clinics involvement into the issues of migration [6] was conducted on all-Russia level. The questionnaire was sent to legal clinics established at 184 Russian universities, from which 67 responses were received, i.e. 67 legal clinics from 6 federal districts, 25 regions of the Russian Federation took part in the survey.

The respondent legal clinics varied greatly in their quantitative characteristics. As a rule, several teachers took part in their work, from 1 to 10 (on average 5). In only one case, the number of teachers was well above average, i.e. in Kazan, 17 teachers. External supervisors were in $2 / 3$ of legal clinics; as a rule, their number ranged from one to several specialists. The number of students participating in the work of legal clinics, as a rule, was 25-30 people. At the same time, there were clinics both with a very small number of students (5-10), and with a very large (100-150 students). Questions of migration law in one way or another were part of the curriculum in $1 / 5$ of the respondent universities. They were taken on average by about 50 students (from 10 to 70 in different universities).

Most of the surveyed legal clinics $(60 \%)$ had experience of working with refugees or migrants. As a rule, there was a small number of regular single requests (1-4 per year) with about half of this experience described as "generally successful". In other clinics, constant requests from migrants and refugees was declared. Only about $1 / 3$ of the surveyed legal clinics did not provide any assistance to migrants and were not interested in working with refugees or migrants.

In general, 2/3 of legal clinics cooperated with various NGOs.

The analytical report on the results of the survey allows us to draw a number of conclusions, which, if desired, can be transformed into practical steps to develop legal clinics for the benefit of law students as well as migrants and refugees.

Firstly, the survey confirms the fact that migrants and refugees do seek assistance of student legal clinics, regardless of whether this area is prioritized in the clinic's work. Given that migrants are much more likely than citizens of the state to become victims of discrimination, with refugees and other forced migrants being even more vulnerable, legal clinics operating at and by universities make an important contribution to increasing the availability of free legal aid for the population. Migrants and refugees who come (in fact) to legal clinics for advice often differ from an "ordinary" visitor of the clinic in terms of questions of their interest. This requires clinicians, students and teachers, to be competent in special legislation. This, at least, implies the need for clinicians to be informed either in the field of special legislation or in terms of competent redirection of questions of such visitors to other available structures, e.g. NGOs, migrants organizations, consulates of migrants citizenship states, etc. Minimal work on the collection and accessibility for clinicians of relevant contact details of such structures is necessary for that.

Secondly, the results of the survey indicate that there is a sufficiently large number of universities in Russia, where special knowledge of migration law is available to students and is in the competence of the teachers. It is $1 / 5$ of respondents, i.e. some 12 universities. The special courses on migrants and refugees forms the potential for developing the skills of clinical students and their mentors in this area, and may be strengthened with involvement of specialists from other universities (for example, those without clinics working with migrants and refugees, but having specialized disciplines and, accordingly, personnel capable of conducting advanced training for students / teachers regarding legal regulation in this area).

The third conclusion concerns the potential of the interaction of student clinics with each other in terms of identifying best practices for working with migrants and 
refugees, and with NGOs in the development of this area of activity of legal clinics. As follows from the analysis of the survey, already at this stage it is possible to reveal, if not very large, but still having a number of legal clinics interested in specific steps to improve their capabilities in working with refugees and migrants. This interest must necessarily find support from universities, competent organizations and other entities.

In other words, it seems that a cautious attitude towards working for the benefit of migrants and refugees in frames of legal clinics operating at Russian universities is partly due to the exaggeration of the difficulties that exist in the implementation of this direction. Survey results dispel at least some of these fears.

\section{ACADEMIC MIGRATION}

It is very remarkable to find target 10.7 (Facilitate orderly, safe, regular and responsible migration and mobility of people, including through the implementation of planned and wellmanaged migration policies) under the heading of Goal 10 'Reduce inequality within and among countries' of the SDGs. This reflects the conceptual vision of migration as a factor capable of increasing or reducing inter-state inequality. The phenomenon of academic mobility, in this context, shows that the states do use migration contrary to their plan under Goal 10 , and even invent concepts justifying such policies and practice.

Academic migration (academic mobility, educational migration, migration of highly qualified personnel) can be considered from two points of view, i.e. as educational migration, that is including academic mobility of students, teachers and scientists, and as labor migration, migration of highly qualified personnel, because scientists and engineers are a part of the labor market. We consider the first meaning of the term.

The concept of 'highly skilled migrants is linked to the tertiary level of education [7, p. 1], as follows from the International Standard Classification of Education, developed by UNESCO, where the third level of education means thirteen or more years of study.

Some researchers consider that migrants are on average educated, e.g. $67 \%$ of migrants arriving to the United States have a secondary education and above; about $88 \%$ of such people arrive in OECD countries [7, p. 3; cf. 8]. Usually, migrants are more educated than the average resident of their country of origin [7, p. 3]. Moreover, the difference can be quite dramatic, e.g. the average duration of education received by migrants from Africa is 15.4 years versus 4.6 years for the average African in Africa, for people from South America these numbers are 12.5 and 5.9, for Asians they are 14.4 and 5.8 , respectively $[9$, p. 125$]$. On the other hand, highly skilled migrants with tertiary education usually make up a small proportion of the highly skilled population of their countries. However, there are exceptions.

The main attraction centers for highly qualified personnel are the United States, OECD countries and the Persian Gulf. However, there is not enough data about the countries of the Persian Gulf for carrying out an analysis [7, p. 7; 10].
Within the framework of academic migration and in context of achieving the SDGs, the concepts of 'brain drain', 'brain circulation' and 'brain waste' shall be presented.

\section{A. "Brain drain"}

The term 'brain drain' was first used in 1962 in the report of the British Royal Society in relation to the migration of scientists, engineers and technicians to the United States [11]. Already in 1968, UNESCO recognized that a 'brain drain' was of national and international interest [11].

'Brain drain' does not mean any outflow of highly qualified specialists, but the one constituting more than $10 \%$ of the proportion of people with tertiary education in the relevant state [7, p. 1]. As a rule, the phenomenon is not about a temporary leaving for abroad, but about emigration. The outflow of human capital causes immeasurably greater harm to the countries of origin than the outflow of financial capital and any other factors of production. This harm is long-term and strategic. Direct losses on the costs of education and the shortfall in taxes are almost nothing in comparison with the loss of human minds and energy, which alone are capable of bringing their countries to a qualitatively new level of development, regardless of whether these are developed or developing states. The comparison of the emigration potential of European and American graduates may be indicative. In Europe, $33 \%$ of graduates expressed a wish to go abroad, to return later wished $13 \%$, while among American graduates, only $18 \%$ would like to leave, and $52 \%$ would like to return [9, p. 131].

For a state, 'brain drain' usually has one of two sides. It is either about selecting the necessary personnel for the economy (for receiving states), or the problem of returning scientists from abroad (for states of origin).

Selective state policy may include such measures as a flexible quota system for workers in demanded specialties with regard to temporary work (as in the USA or the United Kingdom), simplified procedure for hiring specific specialists (as in France or Ireland), providing graduates with the opportunity to stay for beginning (and often, already continuing) work activity [9, p. 144].

The problem of return can be solved by enhancing the attractiveness of the innovation sectors for young scientists (as in Austria by allocating special scholarships, in the Netherlands by targeting thousands of young professionals); by creation of infrastructure in the field of priority scientific research (as is done for biotechnologies in Spain, Germany, Russia); by facilitating the resettlement of scientists and the provision of tax incentives to them [9]. It should be noted that the best solutions are those of a comprehensive character, since exclusively raising wages and/or all forms of material remuneration are not decisive for the return of scientists, as proved by the experience of such countries as South Korea, India [12].

For solving the problems stemming from 'brain drain' and for even preventing it, the cooperation in the field of higher education has enormous and independent significance, for example, as the Bologna process has. 


\section{B. "Brain circulation"}

'Brain circulation' (or 'brain exchange') is a concept born in Western countries in response to the accusations of conscious exploitation and appropriation of the intellectual potential of developing and economically vulnerable states. Its essence lies, in essence, in exaggerating the significance of the reverse movement of scientists, i.e. from the Global North to the Global South, that, of course, takes place, too [10]. Specialists from developed countries migrate to developing countries, e.g., as workers of transnational corporations, thus helping, inter alia, the national institutional building. 'Brain circulation' also includes the interaction of states of origin with diasporas abroad, when such cooperation results in, for example, the creation of joint ventures by emigrants and the citizens of the respective states, as is the case between India and China, on the one hand, and the corresponding diasporas on the other. In addition, in the North-South migration movement there is a significant share of the so-called 'retirement' migration, when individuals, including highly skilled, who have already retired, change their place of residence for a more desirable from the climate and economic perspective, without making an intellectual contribution to the development of the state of their new residence.

It should be recognized that the impact of movement from North to South is not comparable to that of a reverse one, either quantitatively or qualitatively, since, while developed states receive representatives of the science, and engineers, they more often send humanitarians, managers, and retirees.

\section{C. "Brain waste"}

Под растратой умов понимают трудоустройство высококвалифицированного специалиста, которое не соответствует его (ее) уровню квалификации и/или образования, а в худших случаях вообще с ними не связано. В России проблема эта была максимально обострена на национальном уровне в начале 90-х гг. ХХ в., когда ради прокормления своих семей большое число инженеров и проч. ушли в торговлю. В мировом масштабе эта проблеме существует, поставлена, но практически не исследована.

'Brain waste' means the employment of a highly qualified specialist to a position that does not correspond to his/her level of qualification and/or education, and, in the worst cases, is not connected with them at all. In Russia, e.g., this problem was at its peak at the national level in the early 90 s. of the XX century, when, for the sake of simply feeding their families, a large number of engineers, etc. turned into managers, sellers, etc. On a global scale, this problem exists, it is recognized, but practically not researched.

\section{CONCLUSION}

Thus, in addition to the conclusions made in each part, we can generalize that the three points discussed prove that the interaction between migration and education influences the achievement of the SDGs. However, the positive or negative effect that such interaction can have, depends on the sincerity of the wish of each state to implement its international legal obligations in good faith.

\section{ACKNOWLEDGMENT}

This research was financially supported by the Russian Foundation for Humanities, project No. 16-03-50188.

\section{REFERENCES}

[1] Transforming our world: The 2030 agenda for sustainable development Resolution adopted by the general assembly on 25 September 2015. UN Doc. A/RES/70/1. Available from: http://www.un.org/en/ga/search/view_doc.asp?symbol=A/RES/70/1

[2] Global migration trends factsheet / International Organization for Migration, 2015. Available from: http://gmdac.iom.int/global-migrationtrends-factsheet.

[3] The International Migration Report 2017 (Highlights). Available from: https:/www.un.org/development/desa/publications/internationalmigration-report-2017.html.

[4] E. Kiseleva, M. Osipova, N. Emelianova, "The Right to Education for Migrant Children in Light of the Latest General Comments by the UN Treaty Bodies," in: Xiaonan Xiao, Huijuan Xue (Eds.) Proceedings of the 2018 2nd International Conference on Management, Education and Social Science (ICMESS 2018) ASSEHR, vol. 176. P. 1768-1771. Available from: https://www.atlantis-press.com/proceedings/icmess$18 / 25897403$

[5] E.V. Kiseleva, "Teaching refugee law in the system of legal education of Russia," in: A.Kh. Abashidze, E.V. Kiseleva (Eds.) Refugee law and international legal regulation of migration: Proceedings of methodical and scientific-practical workshop on refugee law, Moscow, 15 April, 2016. Moscow: RUDN, 2017, pp. 13-22. (in Russian)

[6] Analysis of the potential of legal clinics in the Russian Federation for the work with refugees and migrants: Analytical report on basis of allRussia survey among legal clinics. Moscow: ST Print, October 2017. (in Russian)

[7] R.H. Adams (Jr.), International Migration, Remittances, and the Brain Drain. A Study of 24 Labor-Exporting Countries. The World Bank. Poverty Reduction and Economic Management Network. Poverty Reduction Group. June 2003.

[8] L. Cerna, "Policies and practices of highly skilled migration in times of the economic crisis," International Migration Papers, No. 99. 2010.

[9] I.P. Tsapenko, "Intellectual migration in developed countries," Science. Innovations. Education. Moscow: Znak, iss. 4, 2008. (in Russian)

[10] Z.L. Kone, Ç. Özden. Brain Drain, Gain, and Circulation. March 2017. KNOMAD WORKING PAPER 19. Available from: https://www.knomad.org/sites/default/files/2017-

04/KNOMAD\%20WP19_Brain\%20Drain\%20gain\%20and\%20circulati on.pdf.

[11] T.V. Chechenkina, N.N. Semenova, "World experience of solving problems of scientific-technical migration and of participation of the diaspora in international cooperation," Science. Innovations. Education. Moscow: Znak, iss. 4, 2008. (in Russian)

[12] V. Feng, H.Chunchang, "PRC: Specificities of migration of high-skilled specialists," A man and labour, vol. 7, 2007. (in Russian) 